\title{
Quinta Michita
}

Arquitectos: Fernando Castillo V., Eduardo Castillo I., Cristián Castillo E. Ubicación: Calle Simón Bolívar, La Reina, Chile Cliente: Comunidad Quinta Michita Cálculo estructural: Fernando Del Sol y asoc. Construcción: Patricio Guzmán y Cristián Del Sol

Materialidad: muros de hormigón proyectado en mallas de acero, paneles aislantes

Presupuesto de la obra: sin datos Superficie terreno $14.200 \mathrm{~m}^{2}$ Superficie construida: $2.500 \mathrm{~m}^{2}$ en viviendas de $100 \mathrm{~m}^{2}$ Año proyecto: 1973

Año construcción: 1978 Dibujo planta: Josefina Vergara, Seminario "Teoría y Práctica del Espacio Doméstico; La Casa y la Arquitectura en Chile, 1950 - 2000", Primavera 2003, E.A.U.C. Escalas: 1: 250, 1: 1000

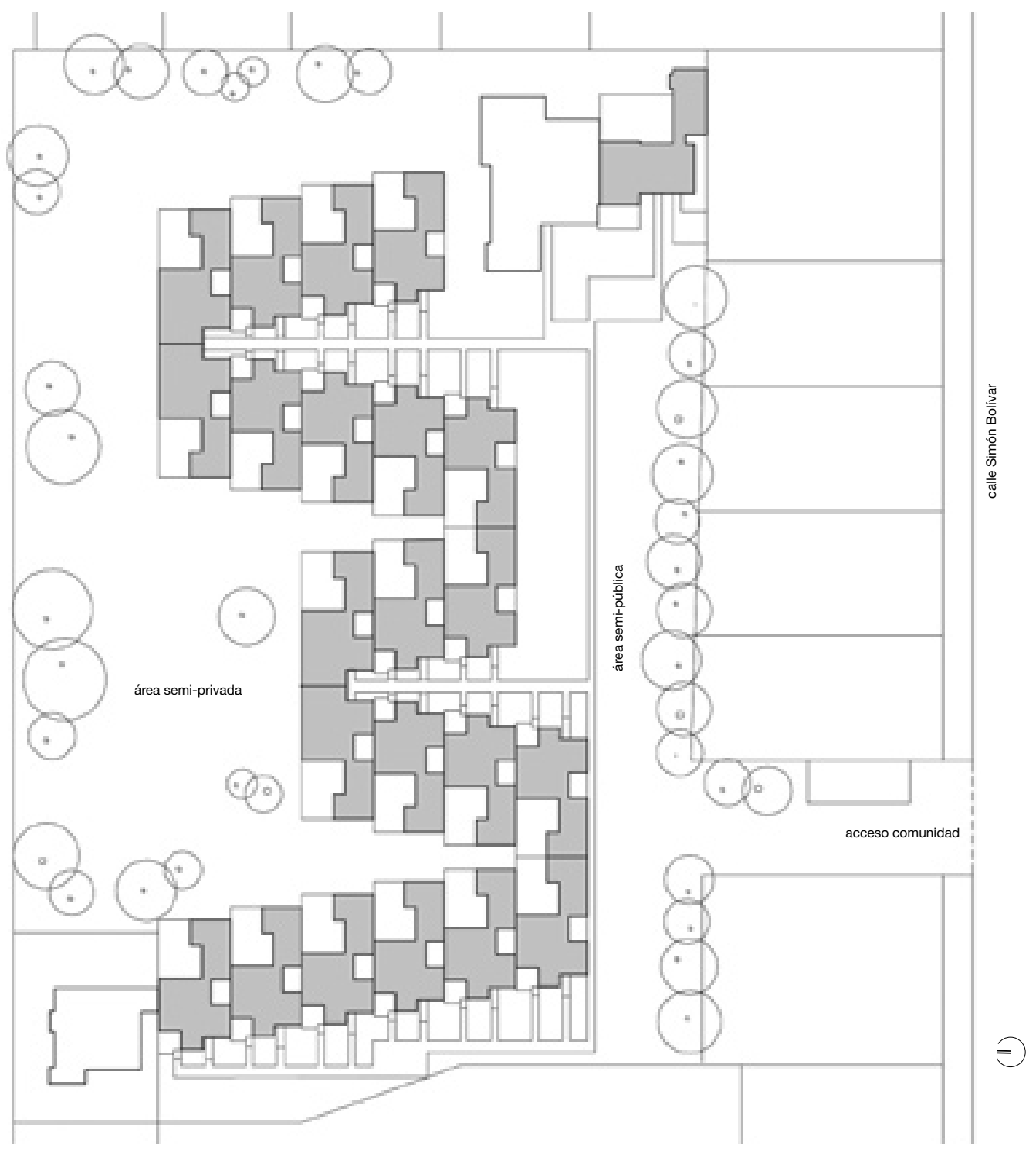

Planta emplazamiento 